\title{
Automatic and Semi Automatic Transaction of Broadcasting and It's Receiving Agent Based M-commerce Business Model
}

\author{
Trivedi Jaydipkumar $\mathrm{H}^{1}$, Trivedi Prakash $\mathrm{H}^{2}$ Thakkar Sunilbhai $\mathrm{T}^{3}$ Makwana \\ Mittal $\mathrm{N}^{4}$ \\ ${ }^{1}$ Assistant professor, Merchant College Of Management Studies And Research,Visnagar,Gujarat,India. \\ ${ }^{2}$ Assistant Professor, G K \& C K Bosamiya College, Jetpur, Gujarat,India. \\ ${ }^{3}$ Assistant professor, Merchant College Of Management Studies And Research,Visnagar,Gujarat,India. \\ ${ }^{4}$ Assistant professor, Merchant College Of Management Studies And Research,Visnagar,Gujarat,India.
}

\begin{abstract}
The Research work would indicate certain m-commerce transaction as automatic transaction and semiautomatic transaction. The work proves Broadcasting and its receiving agent based M-commerce business model based automatic transaction and semi automatic transaction. There is a vital role of embedded system for the automatic business transaction. The advance system is establishing transaction based on present model. Broadcasting and its receiving agent based M-commerce business model perform transaction through (1) T.V Broadcasting, (2) Radio Broadcasting,(3) Telephone Broadcasting,(4) Web casting, (5) Satellite Broadcasting (6) Cable Radio Broadcasting. M-commerce driving factors played important role for the present transactions. Research Inspection Report, questionnaire used as research methodology for proving the automatic and semi automatic transaction based on the present model. The work observes extending transaction of M-commerce based on Broadcasting and its receiving agent based M-commerce business model.
\end{abstract}

Keywords: M-Commerce

\section{INTRODUCTION}

The work has the explanation of the transaction that is based on all the broadcasting agent and its receiving agent. M-commerce broadcasting transaction will be (1) T.V Broadcasting, (2) Radio Broadcasting,(3) Telephone Broadcasting,(4) Web casting, (5)Satellite Broadcasting, (6) Cable Radio Broadcasting. Literature review instructs all the related work. There are certain objectives, out of all objective the work prove automatic and semi automatic transaction and prove the transaction of broadcasting and its receiving agent based $\mathrm{M}$ commerce business model taken as chief objectives. Research inspection report utilized as research methodology. Hypothesis have been taken for tested. Automatic and semiautomatic transaction of the mcommerce model related hypothesis have been depicted.

The role of driving factor indicate variables, activates, equation and result for deciding M-commerce model. There is brief introduction about M-commerce model. Transaction and architecture giving it's individual effect. At last the work has taken practical and real time transactions approach and put its result. Data analyses have been performed on the basis of obtained data.

\section{LITERATURE REVIEW}

M-Payment between Banks Using SMS by Pavan Soni has introduced in his model. M-Payment can done using phone SMS services. ${ }^{[2]}$ It shows the extending payment schemes, Issues, Solution. In his Payment he has used four entitles like (1) Consumer (2) Merchant (3) Banks (4) Mobile Operators. Transaction has been done using MPIN, Mobile Payment Identification Number and Bank Identification. There is some verification between customer and bank. The mobile operators will send the information to the bank and compare the information of the customer. There is one more conformation about the customer's bank account and balance with ID. After the all conformation payment can be done. It is SMS based transaction between customer and market. ${ }^{[2]}$

MIN Qingfei, JI Shaobo, QU Gang have written in his work Mobile Commerce User Acceptance study in china: A Revised UTAUT Model ${ }^{[6]}$ There is UTAUT theory of acceptance and use of technology. There is some theoretical frame work which indicates certain characteristic of M-commerce. China is the place where the research done and taken its case data. ${ }^{[6]}$

Broadcasting and It's receiving Agent Based M-commerce Business Model displayed in the research journal in which whole model depicted M-Commerce based transaction. ${ }^{[3]}$

The model has depicted all the broadcasting Agent and broadcasting receiving Agent based mcommerce business model related transactions. There is architecture for all the m-commerce transactions. Mcommerce Driving Factors and Transaction Variables: Aspects That's Construct the M-commerce Model has 
strengthening the ways of deciding M-commerce Model. The work instructed the concept of M-commerce driving factors and transaction variables are the aspects that construct the m-commerce model. ${ }^{[4]}$ Rapid Growth of Customer Use and Adoption of Broadcasting Agent and Receivers is an advance driving factors considering in the work. ${ }^{[5]}$

The extending work would be automatic and semiautomatic transaction of Broadcasting and its receiving agent based M-commerce business model.

\section{OBJECTIVES}

-Proves the automatic transaction based on Broadcasting and its receiving agent based M-commerce business model.

- Proves the semiautomatic transaction based on Broadcasting and its receiving agent based M-commerce business model.

- Study the m-commerce model.

- Observe the transaction of $\mathrm{m}$-commerce model.

\section{RESEARCH METHODOLOGY}

"Research Inspection Report" using as research methodology. The work needs some observation and inspection for proving the automatic and semiautomatic transaction of broadcasting and its receiving agent based M-commerce business model. The "Research Inspection Report" is taken from businessmen who involved in the automatic and semiautomatic transaction related to the present model. Questionnaire and its results are also using to prove the work.

\section{HYPOTHESIS}

1. There are Automatic and semi automatic transactions of broadcasting and its receiving agent based Mcommerce business model done by the embedded system.

2. The embedded system will do the transaction based on Broadcasting and its receiving agent based mcommerce business model.

\section{ROLE OF DRIVING FACTOR}

The activity of the business transaction is important for deciding the driving factor and for deciding Mcommerce model ${ }^{[4]}$ Among all of the common and general transaction of the business, the driving factors and its activities leads to the selected identification of the M-commerce business model.

Example

\section{Activities}

(Transactions Definition) : DTH based program can be recharged through mobile device using phone based paying services and will obtain goods automatically using different broadcasting or broadcast receiving agent.

\section{Relate Driving Factors To Be Decided By Activities:}

Rapid Growth of Customer Use and Adoption of Broadcasting Agent and Receivers. ${ }^{[5]}$ The present transaction can be converted in to variable. Transaction variable can be useful to decide M-commerce Driving Factors. ${ }^{[4]}$

3. Equation to Be Used For the Selection of the Model:

Now, The driving factor based on transaction variable. ${ }^{[4]}$

$$
\sum_{i=1}^{n} \operatorname{Tr} . \mathrm{V}_{(\mathrm{i})} \rightarrow \mathrm{MDF}
$$

It shows that all the variable that is obtained from transaction from first variable to ' $n$ ' variable is deciding MDF, M-commerce driving factor. And MM, M-commerce model is based on both of the thing (1) Transaction variables and (2) Driving factors. ${ }^{[4]}$

$$
\sum_{i=1}^{n} \operatorname{Tr} . \mathrm{V}_{(\mathrm{i})} \rightarrow \mathrm{MDF} \rightarrow \mathrm{MM}
$$




\section{Result:}

Broadcasting and its receiving agent based M-commerce Business model is the model which represents the activities.

\section{M-COMMERCE MODEL}

\section{Introduction of the M-Commerce Model:}

For the establishment of M-commerce's business transaction, broadcasting and its receiving agent played important role. Broadcasting and its receiving agent based M-commerce business model utilized (1) T.V Broadcasting, (2) Radio Broadcasting,(3) Telephone Broadcasting,(4) Web casting, (5) Satellite Broadcasting (6) Cable Radio Broadcasting as broadcasting agent. ${ }^{[3]}$

There are its related receiving agents for each broadcasting agent. Between receiving agent and its broadcasting agent there is broadcasting based network or $3 \mathrm{G}$ network. The customer establishing business transaction on the basis of broadcast receiving agent can display. As per the architecture depiction the present model is working and establishing the M-commerce business transaction. The architecture indicated automatic and semiautomatic transaction.

Customer is establishing transaction on his own mobile device and purchasing the item as business activity. The model depiction indicate the possible use of certain technology e.g. Sensor device at the message sending side. At the same side there is an alternate use of the mobile phone for sending message or dialing for order. But the message sending and dialing is not a simple dialing. There are certain websites, telephone services, and internet services which strengthening the business transaction. There is NFC Network, Sensor Network, or WSN network for processing the transaction. The network can be selected as per transaction done. The combining activities of (I) order receiving agents, (II) Data authentication and credit conformation and (III) the activities of business firm using different embedded system. The automatic transaction initiate the goods distribution automatically. The customer obtained the goods as DTH program and its recharge or as telephone recharge. The broadcasting agents and its receiving agents are supporting the goods to be available automatically. If the customer is watching the DTH program by recharging automatically using certain system then it may be regarded as automatic transaction.

The semi automatic transaction of the present model can be considered using the partial use of technology which is used in automatic transaction. The business transaction start from the customers side using mobile. The customer is receiving information through broadcasting receiving agents and establish business transaction using mobile device or directly from the shopping mall or any shops. But for some times, paying the cost using telephone money like Airtel Money, Reliance Money, or any internet or mobile banking services. As per the depiction of the architecture customer start transaction using mobile devices. Before it he got information from broadcasting receiving agent. There are order sending agents which send the order. There are broadcasting based network or 3G network. Data authentication perform simultaneously at order receiving area. The business firm is providing the goods physically or automatically to the customer.

\section{Architecture of the Model:}

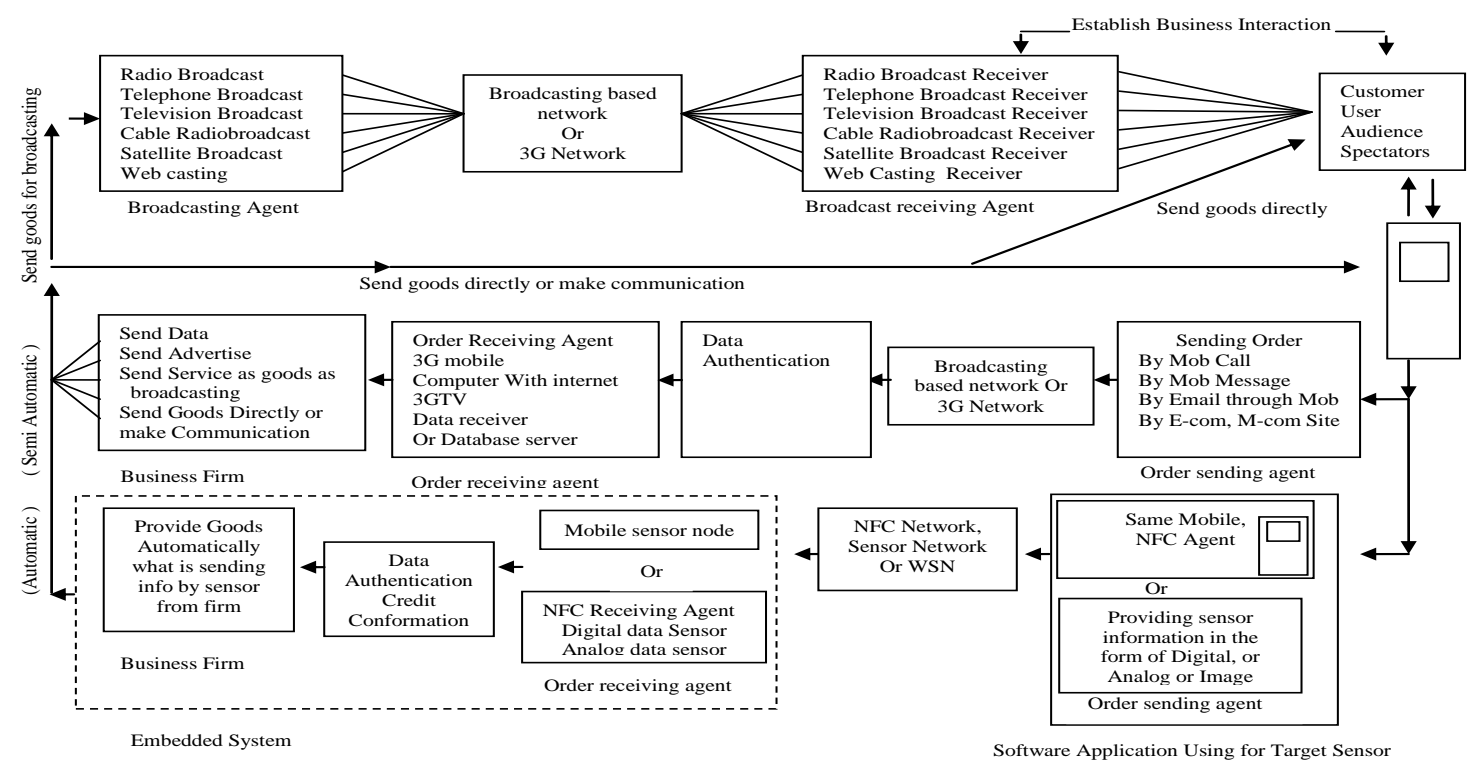

Figure 1 Architecture of the Broadcasting and its receiving agent based M-commerce business model 


\section{TRANSECTION}

There are numbers of business transaction occurs. As per the present m-commerce model the work is indicating (1) Automatic transactions and (2) Semi automatic transactions. The "Research Inspection Report" played great part for observing automatic transaction and semi automatic transaction based on broadcasting and its receiving agent based M-commerce business model.

\section{(I) CONSIDER THE AUTOMATIC TRANSACTIONS:}

As per the architecture of the broadcasting and its receiving agent based M-commerce business model below mention are its transaction.

Transaction 1: Purchasing an item that is on a screen as T.V broadcasting at a shopping mall.

M-Commerce Transaction Type: T.V Broadcasting

1. Item To Be Purchased: Recharge the mobile bill by using Airtel Money on mobile phone from an advertise broadcasted at shopping mall at cites situated at Gujarat state in India.

2. Item Display Tools: T.V Sets Displays at Mall, Digital Display, Simple Electric Display.

3. Item Broadcasting Tools: T.V Broadcasting. That is installed at shopping mall and it has T.V/Dish TV/Channel Connections The Commercial Information as an advertise displaying on it either in a Video Audio form.

4. Data Source: Filled RIR, Research Inspection Report and obtained fact based on transaction done.

5. Data Combination Used By Whole System:

\begin{tabular}{|l|l|l|}
\hline No & Items & Description \\
\hline 1 & Electric Power & $1000 \mathrm{uf} / 25 \mathrm{~V}$ \\
\hline 2 & Digital Data as 01 & Bits \\
\hline 3 & Waves used by Mobile Telephone & High Frequency Radio Waves \\
\hline
\end{tabular}

6. Total Hardware Software Used:

\begin{tabular}{|l|l|l|}
\hline No & Items & Description \\
\hline 1 & LCD & $16^{*} 12$ \\
\hline 2 & Microcontroller & 8051 and AT89x \\
\hline 3 & Barcode Reader Modem & $\begin{array}{l}\text { Capacity to work with UART } \\
\text { protocol }\end{array}$ \\
\hline 4 & Transformer & $12 \mathrm{~V}$ \\
\hline 5 & Filter & $1000 \mathrm{uf} / 25 \mathrm{~V}$ \\
\hline 6 & Voltage Regulator & $7805 / 7812$ \\
\hline 7 & Mobile Software System & Andoid \\
\hline 8 & Computer Software System & .Net Framework with C\# \\
\hline
\end{tabular}

7. Services to Be Used:

\begin{tabular}{|l|l|l|}
\hline No & Items & Description \\
\hline 1 & Internet Services & $\begin{array}{l}\text { Broadband Services for the system. BSNL Broad } \\
\text { Band Internet Services. }\end{array}$ \\
\hline 2 & $\begin{array}{l}\text { Banking Services with } \\
\text { Internet }\end{array}$ & $\begin{array}{l}\text { Banking Computer Server and Its related Banking } \\
\text { Credit Card and Debit Card using Authentication } \\
\text { and Credit conformation. } \\
\text { State Bank Of India is a bank functioning with. }\end{array}$ \\
\hline 3 & $\begin{array}{l}\text { Mobile Phone Services like } \\
\text { (i) General Telephony } \\
\text { Services (ii) Airtel Money } \\
\text { Services }\end{array}$ & $\begin{array}{l}\text { Sebile Phone Company Services and Computer } \\
\text { Server using for Authentication and Credit } \\
\text { Airtel Mobile Phone used with }\end{array}$ \\
\hline
\end{tabular}

8. Fact to be obtained by RIR Research Inspection Report: Data Attached Data Attached

1. Transaction Bill that is done using Airtel Money.

(i) Hard Copy (ii) Soft Copy

2. Photo of the display screen and transaction.

3. Transaction Details.

9. Transaction Destination: Shopping Moll.

10. Possibility to utilization of advance system:

Square ${ }^{[1]}$ Square can be used with iPhone for credit card swipe. A Device can be added to the audio jeck of iPhone. 
Transaction 2: Purchase an item using mobile that is broadcasting on a Radio service based on DTH (Direct To Home) from a home or Radio Transmission receiver at home.

M-commerce Transaction Type: Radio Broadcasting (Direct To Home)

1. Item To Be Purchased: Recharge the Airtel Dish TV

recharged by using Airtel Money on mobile phone from

an advertised broadcasted on a T.V based radio (DTH

Radio) at home at Visnagar cites situated at Gujarat state

in India.

2. Item Display Tools: Radio Transmission Receiver on T.V Sets Displays At Home

3. Item Broadcasting Tools: Radio Transmission based T.V Broadcasting. That is installed at home and it has T.V/Dish TV/Channel Connections. Radio Transmission Receiver is also available on Mobile phone as "Radio Transmission Receiver", T.V as "Radio Transmission Receiver". LapTop Or Desktop Computer as Radio Transmission Receiver. The Commercial Information as advertise displaying on it either in a Voice or Sound form.

4. Data Source: Filled RIR, Research Inspection Report and obtained fact while transaction occur.

\section{Data Combination Used By Whole System:}

\begin{tabular}{|l|l|l|}
\hline No & Items & Description \\
\hline 1 & Electric Power & 1000 uf/25V \\
\hline 2 & Digital Data as 01 & Bits \\
\hline 3 & Waves used by Mobile Telephone & High Frequency Radio Waves \\
\hline 4 & Analog Data & Voice type data \\
\hline
\end{tabular}

6. Total Hardware and Software Used:

\begin{tabular}{|l|l|l|}
\hline No & Items & Description \\
\hline 1 & LCD & $16^{*} 12$ \\
\hline 2 & Microcontroller & 8051 and AT89x \\
\hline 3 & DTH Setup Box as receiving tool & Receiver that receive data from satellite \\
\hline 4 & Transformer & $12 \mathrm{~V}$ \\
\hline 5 & Voltage Regulator & $7805 / 7812$ \\
\hline 6 & $\begin{array}{l}\text { Computer Software System, Software of } \\
\text { Radio Waves Transmission Receiver on } \\
\text { T.V, Mobile Phone, Laptop, Computer, } \\
\text { Tablet, or Radio as Radio waves receiver. }\end{array}$ & \\
\hline
\end{tabular}

7. Services to Be Used:

\begin{tabular}{|l|l|l|}
\hline No & Items & Description \\
\hline 1 & Internet Services & $\begin{array}{l}\text { Broadband Services for the system. BSNL Broad } \\
\text { Band Internet ervices. }\end{array}$ \\
\hline 2 & Banking Services with Internet & $\begin{array}{l}\text { Banking Computer Server and Its related Banking } \\
\text { Credit Card and Debit Card using Authentication and } \\
\text { Credit Conformation. } \\
\text { State Bank Of India is a bank functioning with. }\end{array}$ \\
\hline 3 & $\begin{array}{l}\text { Mobile Phone Services like (i) } \\
\text { General Telephony Services } \\
\text { (ii) Airtel Money Services }\end{array}$ & $\begin{array}{l}\text { Mobile Phone Company Services and Computer } \\
\text { Server using for Authentication and Credit } \\
\text { Conformation. } \\
\text { Airtel Mobile Phone used with }\end{array}$ \\
\hline
\end{tabular}

8. Fact to be obtained by RIR, Research Inspection Report: Data Attached in RIR

1. Transaction Bill that is done using Airtel Money.

2. Photo of the display screen and transaction.

3. Transaction Details.

4. Audio Video File

9. Transaction Destination: Home

10. Possibility to utilization of advance system

- 3G T.V using as radio Transmission Receiver

- 3G Phone using as radio Transmission Receiver 
- Teblet/Leptop using as radio Transmission Receiver.

Transaction 3: Purchase an item using internet Web that is Web casting done through a computer node using internet on mobile (mobile as computer node).

M-commerce Transaction Type: Web casting

1. Item To Be Purchased: Purchase a pen drive that is advertised on a websites as web casting (receive broadcasting at all IP) and paying by using internet banking on mobile phone. Some time web casting is done at targeted, selected IP (Internet Address) and advertise will be at these selected node on internet.

2. Item Display Tools: Web casting display on a internet competent mobile working as computer node.

3. Item Broadcasting Tools: =Mobile Phone with internet competency and display the commercial Information as advertise displaying on it either in a Voice or Sound and Web Site advertise form.

4. Data Source: Filled RIR, Research Inspection Report and obtained fact while transaction occur.

5. Data Combination Used By Whole System:

\begin{tabular}{|l|l|l|}
\hline No & Items & Description \\
\hline 1 & Electric Power & $1000 \mathrm{uf} / 25 \mathrm{~V}$ \\
\hline 2 & Digital Data as 01 & Bits \\
\hline 3 & Waves used by Mobile Telephone & High Frequency Radio Waves \\
\hline 4 & Analog Data & $\begin{array}{l}\text {-Telephone Voice } \\
\text {-continues electrical signal look like } \\
\text { a sine waves. }\end{array}$ \\
\hline
\end{tabular}

6. Total Hardware and Software Used:

\begin{tabular}{|l|l|c|}
\hline No & Items & Description \\
\hline 1 & Telephone or Mobile Phone & Semsung \\
\hline
\end{tabular}

7. Services to Be Used:

\begin{tabular}{|l|l|l|}
\hline No & Items & Description \\
\hline 1 & Mobile Telephone Services (MTS) & $\begin{array}{l}\text { Pre Cellular or VHF radio system which is } \\
\text { linked to PSTN Public Switched Tele. Network }\end{array}$ \\
\hline 3 & Internet Services & $\begin{array}{l}\text { Broadband Services for the system. BSNL } \\
\text { Broad Band Internet Services. }\end{array}$ \\
\hline 4 & Banking Services with Internet & $\begin{array}{l}\text { Banking Computer Server and Its related } \\
\text { Banking Credit Card and Debit Card using } \\
\text { Authentication and Credit conformation. } \\
\text { State Bank Of India is a bank functioning with. }\end{array}$ \\
\hline 5 & Currier Service & Blue D \\
\hline
\end{tabular}

8. Fact to be obtained by RIR, Research Inspection Report: Data Attached in RIR

1. Transaction Bill that is done using Internet Banking.

2. Photo of the display screen and transaction.

3. Transaction Details.

4. Audio Video File

9. Transaction Destination: Computer node as mobile phone.

10. Possibility to utilization of advance system - 3G Mobile Phone, Square ${ }^{[1]}$

(II) CONSIDER THE SEMI AUTOMATIC TRANSACTIONS:

\section{Transaction 1:}

Purchasing an item that is on speakers at shopping mall as broadcasting \ Local offer based broadcasting at a shopping mall and payment is transferring cash but transferring balance or payment in bank account of Shopping Moll.

M-commerce Transaction Type: audio Speaker based Local information Broadcasting at Mall

1. Item To Be Purchased:

Purchase a book from a mall, an advertised broadcasted on a Audio Speakers settled in Shopping Moll at Ahmedabad cites situated at Gujarat State in India. 


\section{Item Display Tools:}

An Audio speakers settled in Shopping Moll

\section{Item Broadcasting Tools:}

An Audio System.broadcasting the information through Mike, Audio recording displayer like Computer System, Leptop, External DVD/CD Player, External Tap Recorder etc.The Commercial Information as advertise displaying on it either in a Voice or Sound form.

4. Data Source: Filled RIR, Research Inspection Report and Obtained fact while transaction occurs.

5. Data Combination Used By Whole System:

\begin{tabular}{|l|l|l|}
\hline No & Items & Description \\
\hline 1 & Electric Power & $1000 \mathrm{uf} / 25 \mathrm{~V}$ \\
\hline 2 & Digital Data as 01 & Bits \\
\hline 4 & Analog data & \\
\hline
\end{tabular}

6. Total Hardware and Software Used:

\begin{tabular}{|l|l|l|}
\hline No & Items & Description \\
\hline 1 & LCD & $16 * 12$ \\
\hline 2 & Microcontroller & 8051 and AT89x \\
\hline 3 & DTH Setup Box as receiving tool & \\
\hline 4 & Transformer & $12 \mathrm{~V}$ \\
\hline 5 & $\begin{array}{l}\text { Combined computer, printer System, } \\
\text { Barcode reader }\end{array}$ & $\begin{array}{l}\text { An advance embedded } \\
\text { system }\end{array}$ \\
\hline 6 & Voltage Regulator & $7805 / 7812$ \\
\hline 7 & $\begin{array}{l}\text { Computer Software System, Software } \\
\text { of Audio file display on Speaker, T.V }\end{array}$ & .Net Framework with C\#, \\
\hline
\end{tabular}

7. Services to Be Used:

\begin{tabular}{|l|l|l|}
\hline No & Items & Description \\
\hline 1 & Internet Services & $\begin{array}{l}\text { Broadband Services for the system. BSNL Broad } \\
\text { Band Internet Services. }\end{array}$ \\
\hline 2 & Banking Services with Internet & $\begin{array}{l}\text { Banking Computer Server and Its related Banking } \\
\text { Credit Card and Debit Card using Authentication and } \\
\text { Credit conformation. } \\
\text { State Bank Of India is a bank functioning with. }\end{array}$ \\
\hline 3 & $\begin{array}{l}\text { Mobile Phone Services like (i) } \\
\text { General Telephony Services (ii) } \\
\text { Airtel Money Services }\end{array}$ & $\begin{array}{l}\text { Mobile Phone Company Services and Computer } \\
\text { Server using for Authentication and Credit } \\
\text { conformation. a } \\
\text { Airtel Mobile Phone used with }\end{array}$ \\
\hline
\end{tabular}

8. Fact to be obtained by RIR, Research Inspection Report: Data Attached in RIR

1. Transaction Bill that is done using Airtel Money.

2. Photo of the display screen and transaction.

3. Transaction Details.

4. Audio File

9. Transaction Destination: Shopping Mall

10. Possibility to utilization of advance system

IX. DATA ANALYSIS

1. Transaction 1: Automatic Transaction

1.1 Customer Utilized Broadcasting Agent and Its Receiver Name: T.V Broadcasting display and doing transaction at shopping moll at Ahmedabad In India. 


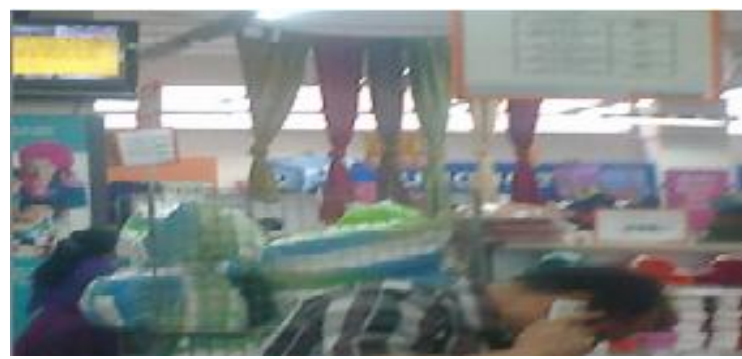

1.2 Data to be obtained for the transaction: Resulting message taken.

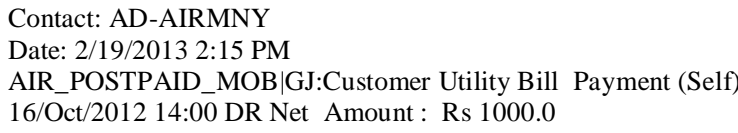

\subsection{Screen Shot Of the Transaction Done}

\begin{tabular}{|c|c|c|c|}
\hline Mestajes & & & \\
\hline 1 -ontat & late/I me & Stavs & Sie Shect \\
\hline -9139:45:99117 & $1 / 20 / 2013 \div 10 \ldots$ & - $0 \dot{x}$ & 1k You have 2 rinied $C$ alliff \\
\hline-913998257454 & $1 / 290 / 2013+24 \ldots$ & $9 \sqrt{2}$ & 1k. Nme Ji uriveraty, orijur \\
\hline$-913986531 \% 70$ & $1 / 7 / 20135,14 \ldots$ & 90 & $1 \mathrm{k}$ Incoming message s notd \\
\hline -9179855117n & 1 1A7/113514 & al $4 x$ & 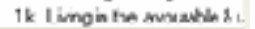 \\
\hline DO ANFMINY & भश्रण13 215 . & 04 & 1k Teld 65147232 AR_P0S \\
\hline$A[-550001$ & $1 / 24 / 20136: 11 \ldots$ & (1) & Ik. 150Local+510 5N5 Fail \\
\hline
\end{tabular}

1.4 Research Inspection Report : Customer has filled The data of the transaction done at moll.

\section{At Part I of RIR}

Question Answer

(1) Do you purchase any thing from the business firm or here?

(Yes)

(2) Do you use automatic payment system of the purchase as business Transaction? (Yes)

(3) Do you get any fact as documents to be obtained form the business transaction ? Other form of Document

(4) Do you sell any thing?

( NO)

(5) Do you use online services for business transaction?

(6) Do you use internet for business transaction

(Yes)

\section{At Part II of RIR}

(1) Indicates the items have parched in one or two words or in sentences.

Ans: Use of Airtel money for postpaid bill

(2) Indicate the payment systems that you used as business transaction.

Ans: Debt card and Net Banking

(3) Name the web sites you have used

Ans: $\underline{\text { www.Airtel.in }}$

2.1 Transaction 2: Automatic Transaction

2.2 Customer Utilized Broadcasting Agent and Its Receiver Name:

Radio Transmission Receiver Using DTH services. Whole Video File of transaction attached in RIR, Research Inspection Report for the reference.

2.3 Data to be obtained for the transaction: Resulting message taken.

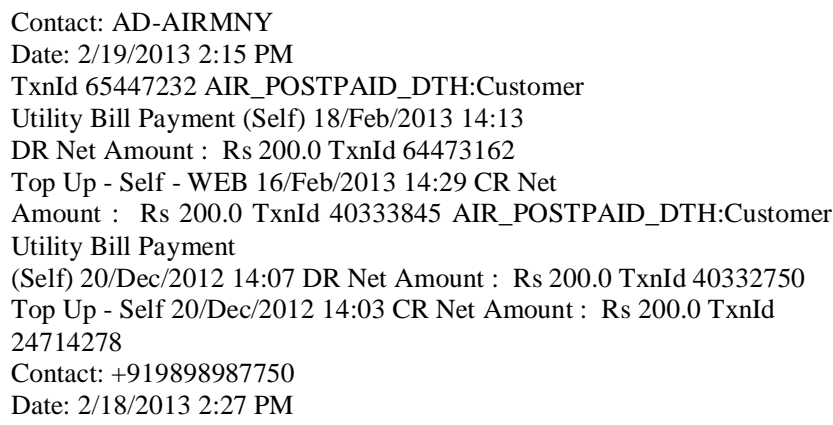




\subsection{Screen Shot Of the Transaction Done}

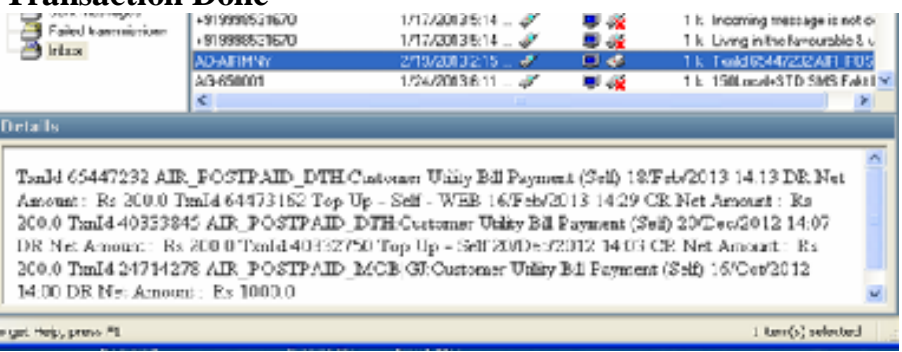

\section{Question}

At Part I of RIR

(1) Do you purchase any thing from the business firm or here?

(Yes)

(3) Do you use automatic payment system of the purchase as business Transaction?

(4) Do you get any fact as documents to be obtained form the business transaction ? Other form of Document

(5) Do you sell any thing?

\section{( NO)}

(6) Do you use online services for business transaction?

(7) Do you use internet for business transaction

\section{At Part II of RIR}

(1)Indicates the items have parched in one or two words or in sentences.

Ans: Use of Airtel money for DTH TV Program bill

(2) Indicate the payment systems that you used as business transaction.

Ans: Debt card and Net Banking

(3)Name the web sites you have used

Ans: www.Airtel.in

3.1 Transaction 3: Automatic Transaction

3.2. Customer Utilized Web casting Agent

and Its Receiver Name: Computer Node, Mobile as

Computer Node

3.3. Data to be obtained for the transaction: Resulting message taken.

$$
\begin{gathered}
\text { Dear Customer, Your Order No. } 920709123 \text { for } \\
\text { product: Transcend 4GB MicroSD Memory Card - Class } 4 \\
\text { has been shipped vide AWB no. } 59094329755 \text { through }
\end{gathered}
$$

3.4 Research Inspection Report : Customer him self has filled data of the transaction done at moll.

\section{Question}

\section{Answer}

(1) Do you purchase any thing from the business firm or here? (Yes)

(2) Do you use cash payment system of the purchase as business Transaction?

(Yes)

(3) Do you get any fact as documents to be obtained form the business transaction ? Other form of Document

(4) Do you sell any thing? ( NO)

(5) Do you use online services for business transaction?

(6) Do you use internet for business transaction

(Yes)

(7) Do you use any extra services (Yes)

\section{At Part II of RIR}

(1) Indicates the items have parched in one or two words or in sentences.

Ans: Transcend 4 GB Pen drive

(2) Indicate the payment systems that you used as business transaction.

Ans: Partial Payment (1) Automatic (2) COD

(3) Name the web sites you have used

Ans: www.homeshop18.com

4.1 Transaction 1: Semi Automatic Transaction

4.2 Customer Utilized broadcasting Agent and Its Receiver Name: Local speaker at Shopping Moll

$$
\text { www.iosrjen.org }
$$




\subsection{Data to be obtained for the transaction:}

Screen Shot of Purchasing bill the item.

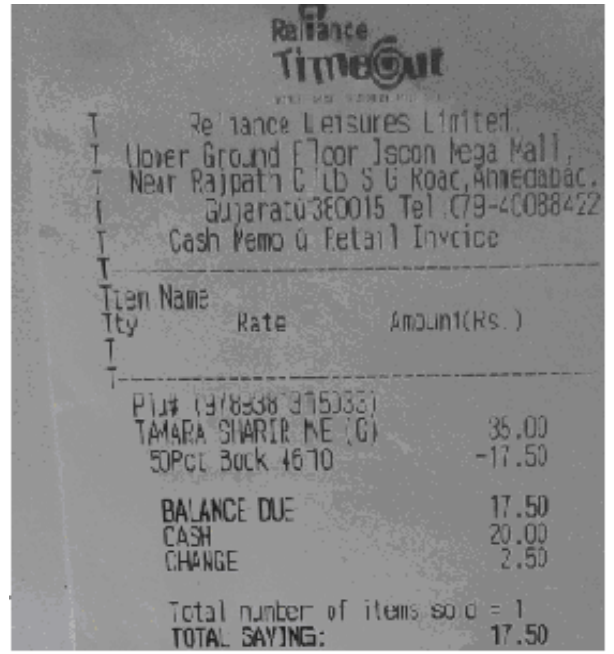

4.4 Research Inspection Report : Customer him self has

filled the data of the transaction done at moll.

\section{Ouestion}

At Part I of RIR

(1) Do you purchase any thing from

the business firm or here? (Yes)

(2) Do you use cash payment system of the purchase as business Transaction?

\section{Answer}

(3) Do you get any fact as documents to be obtained form the business transaction? Other form of

\section{Documents}

(4) Do you sell any thing?

( NO)

(5) Do you use online services for business transaction?

(6) Do you use internet for business transaction

(Yes)

(7) Do you use any extra services

(8) Do you use automatic payment system of the purchase as a business Transaction.

\section{At Part II of RIR}

(1)Indicates the items have parched in one or two words or in sentences.

Ans: A book from the Shopping Moll

(2) Indicate the payment systems that you used as business transaction.

Ans: (1) Automatic (2) Cash

\section{RESULT AND CONCLUSSION}

Result of the Transaction 1: M-Commerce Transaction starting from the customer who has placed the order and at the end obtained goods automatically and used broadcasting services.

1. Used device for the information as an advertise display.

$$
=\text { TV Broadcasting at Moll }
$$

2. Used automatic device for placing order $=$ Mobile device

3. Used automatic device for receiving goods $=$ Mobile device

4. All the transaction section using automatic transaction=

(i) Business Firm is sending goods automatically.

(3) Authentication perform automatically

(4) Credit Conformation performs automatically.

(5) Goods to be obtained automatically.

5. Report of RIR, Research Inspection Report

- At part I there are 3 answer that indicates 'YES' out of 8 
Answer.

- At part II there is 1 answer that indicates 'Automatic Transactions' out of 2 answers.

6. Automatic Form of Goods: "Recharge the telephone bill Credit", automatically using Broadcasting agent and Broadcasting receiver.

Result of the Transaction 2: M-Commerce Transaction starting from the customer who has placed the order and at the end obtained goods automatically and used broadcasting services.

1. Used device for the information as an advertise display. =Radio Transmission Receiver Using DTH service

2. Used automatic device for placing order $=$ Mobile device

3. Used automatic device for receiving goods $=\mathrm{TV}$ as Broadcasting receiver

4. All the transaction section using automatic transaction=

(1) Business Firm is sending goods automatically.

(3) Authentication perform automatically

(4) Credit Conformation performs automatically.

(5) Goods to be obtained automatically.

5. Report of RIR, Research Inspection Report

- At part I there are 3 answer that indicates 'YES' out of 8

Answer.

- At part II there is 1 answer that indicates 'Automatic

Transactions' out of 2 answers.

6. Automatic Form of Goods: "Recharge the DTH Program Bill Credit", automatically using Broadcasting agent and Broadcasting receiver.

Result of the Transaction 3: M-Commerce Transaction starting from the customer who has placed the order and at the end obtained goods Partial automatically and used broadcasting services.

1. Used device for the information as an advertise display. =Web Casting at Node

2. Used automatic device for placing order $=$ Mobile device

3. Used automatic device for receiving goods $=$ No

4. All the transaction section using automatic transaction=

(1) Business Firm is sending goods automatically.

(3) Authentication perform automatically

(4) Credit Conformation performs automatically.

(5) Goods to be obtained not fully automatically.

5. Report of RIR, Research Inspection Report

- At part I there are 4 answer that indicates 'YES' out of 9

Answer.

- At part II there is 1 answer that indicates 'Automatic

Transactions' out of 2 answers.

6. Automatic Form of Goods: No, Purchase 4 GB Pen Drive from the Website. So receive goods physically.

Result of the Transaction 4: M-Commerce Transaction starting from the customer who has placed the order and at the end obtained goods Semi automatically and used broadcasting services.

1. Used device for the information as an advertise display. =Speaker based local broadcasting at Moll

2. Used automatic device for placing order $=$ No

3. Used automatic device for receiving goods $=$ No

4. All the transaction section using Semi automatic transaction=

(1) Business Firm is sending goods Semi automatically.

(3) Authentication perform Semi automatically

(4) Credit Conformation performs automatically.

(5) Goods to be obtained not fully automatically.

5. Report of RIR, Research Inspection Report

- At part I there are 5 answer that indicates 'YES' out of 9

Answer.

- At part II there is 2 answer that indicates 'Semi Automatic Transactions' out of 3 answers.

6. Semi Automatic Form of Goods: Yes, Purchase Book from the Shopping from the shopping Moll.

\section{Hypothesis Test Data}

1.There are Automatic and semi automatic transactions of broadcasting and its receiving agent based Mcommerce business model done by the embedded system. - Data analysis indicates Four Transaction using 
individual Computer and electronic system for their transaction. Observe the individual different system for each.

2. The embedded system will do the transaction based on Broadcasting and its receiving agent based m-ommerce business model. - Yes, It is performed in all the transaction that we can observed through the data and through transaction. An architecture is also consider the transaction.

\section{REFERENCES}

[1] Square, http://en.wikipedia.org/wiki/ Square_\%28application\%29

[2] Pavan Soni, M-Payment Between Banks Using SMS, 2010 IEEE Vol.98, No.6, June 2010

[3] J H Trivedi, Dr J G Pandya,Dr. A N Jani, PH Trivedi Broadcasting and It's receiving agent based Mcommerce model. As Poster Presentation displayed in International Seminar at H.N.G.University,Patan. India. And gone for Publishing in the University Journal.

[4] Trivedi J H, Dr. J G Pandya, J M Patel, Mithapara Anita, M-commerce Driving Factors and Transaction Variables: Aspects That's Construct The M-commerce Model, IOSR Journal of engineering Vol. 1, Issue 2,pp.135-141

[5] J H Trivedi, Dr J G Pandya, PH Trivedi, J B Patel Rapid Growth of Customer Use and Adoption of Broadcasting Agent and Receivers.

[6] MIN Qingfei, JI Shaobo, QU Gang, Mobile Commerce User Acceptance study in china: A Revised UTAUT Model. ISSN 1007-0214 01/26 pp257-264 Vol 13,Number 3, June 2008 